\title{
A preliminary comparative perspective on the role of multinational enterprises in influencing labour relations of their host nation
}

\author{
Cok Allen-ILE \\ Department of Industrial Psychology, \\ Faculty of Economic \& Management Sciences, \\ University of the Western Cape, Cape Town \\ Oj Olabiyi \\ Department of Industrial Psychology, \\ Faculty of Economic \& Management Sciences, \\ University of the Western Cape, Cape Town
}

\begin{abstract}
This paper examines the operations of multinational enterprises (MNEs) in so far as they are able to influence the public and labour relations policy and law of their host nation with a special attention on African nations. It is to be expected that MNEs would already be comfortable with the mechanisms in place for the resolution of labourrelated or commercial disputes in their country of origin. The question then that arises is: If confronted with an employment relations situation in their host nation, would the MNE attempt to circumvent or adapt the process to suit what they are already familiar with? This could pose a challenge for the practice of international labour law. Literature (Briscoe, Schuler \& Tarique, 2012; Eweje, 2009; Iyanda \& Bello, 1979; Onimode, 1978) already alludes to the fact that MNEs tend to take the 'line of least resistance' if confronted with 'higher' labour standards. A comparative exploratory analysis was undertaken. The paper identified MNEs in selected African countries Nigeria, South Africa, and Zambia - that have been reported to have had a challenge in dealing with labour-related or commercial standards of their host nation. The selected MNEs had been reported in the news media for having had a 'run in' with their host nation on, at least, a labour - or commercial law-related matter. The principal legislation governing labour relations in these countries are, in some cases, briefly highlighted to underscore the extent of their breach or disregard by the examined MNEs. Furthermore, a qualitative, thematic analysis of selected reported cases involving these MNEs were undertaken to highlight evidences (or instances) of attempts, if any, by the MNEs to circumvent the commercial, fiscal or labour standards of the host nation. Finally, it is hoped that the result of the above analyses would inform the possibility of proposing a framework for MNEs compliance with the labour standards of their host nation.
\end{abstract}

Key Words: Multinational Enterprises, Multinational Corporations, Transnationals, Globalization, Labor Relations, International Labour Organisation, Unions, Comparative Labour Legislation, Africa

\section{INTRODUCTION AND BACKGROUND}

The emergence of multinational enterprises (MNEs), or multinational corporations (MNCs) and transnational corporations, as they are also referred to, could be traced to the advent of the industrial revolution, and concomitantly, the onset of colonialism in the $17^{\text {th }}$ and $18^{\text {th }}$ 
centuries ${ }^{1}$. However, (MNEs) did not operate in a vacuum without some form of influence on and from the host environment. This influence would have been in the form of trade or economic policies, which have been well documented (Burton, Bloch \& Mark, 1994; Richard, 2007; Tyler, 1993). The operations of multinational enterprises also had an influence on price, consumer and market behavior that apparently led to an influence on the labour or employment relationship that exist in the host environment (Zhao, 1998).

In influencing this employment relationship environment, multinational enterprises go further to influence the labour relations policy, and possibly the labour laws of the host country (Frenkel \& Peetz, 1998; Stopford, 1998. For example, what happens if a multinational enterprise refuses to observe the labour laws of the host nation, how will the government sanction it? Are there any procedures or regulations, pre-established by the host nation's legislative framework, for dealing with such transgressions? Often times, governments do not have pre-existing mechanisms to keep them in-check.

Labour 'standard' relates to how the government has pitched the nature and quality of the relationship that should be maintained by all the parties to the employment relationship in that particular environment. The main focus of employment or labour standards is usually on how workers should be treated. This standard applies equally to both domestic and multinational enterprises. Suppose the employment standard is too high and the multinational enterprise would rather that the employment standard is lower, for whatever reason. In what ways can a multinational enterprise attempt to subvert the employment standard of the government of the host nation? It is plausible that MNEs can employ a variety of tactics to circumvent this standard. In South Africa for example, the labor legislative regime is very rigid and protective of worker rights. Some employers, including MNEs, have voiced their complaints against this protection ${ }^{2}$. For example, sections 51, 161 and 167 of the Labor Relations Act (LRA) Number 66 of 1995, as amended, prescribe due statutory processes and mechanisms for the resolution of disputes which some employers may find extremely onerous and demanding. This has sometimes, rightly or wrongly, being cited as one of the reasons for the reluctance of certain MNEs to invest in the country.

In view of the above labour standard, one of the avenues that may be open to an unscrupulous employer to attempt to circumvent the labour relations system could be in the area of the dispute resolution mechanism currently in place. For instance, the process provides for parties to follow specific steps in resolving disputes between them. It is, also, clearly statutorily provided for by the LRA that before a union or workers can embark on strike action, there are procedural requirements to be followed. The union or workers must apply for a right to strike and for the strike to be recognized it must be a protected strike, for the strike to be protected the employer must agree or acknowledge and issue a certificate for them to embark upon such a strike. What will happen if the employer deliberately refuses to give approval for such strike because such employer has an ulterior motive, and, may want to advance the excuse that the strike was not a 'protected' one in order to dismiss those striking workers for the purpose of employing new workers and by that act sidestep the labor relations process and the law.

In contrast to the above, rigid, statutory labour relations system, a country like Nigeria does not have a framework like that of South Africa. In fact, the framework that exists does not apply

\footnotetext{
1 Barton, R. \& Bishko, M. (1998). “Global mobility strategy" Human Resource Focus.

2 In South Africa, the likelihood that this sort of resistance may arise was predicted and anticipated very early on in the implementation of the Act by the likes of Brand, J.; Lotter, C; Miscke, C. \& Steadman, F. (1997) Labour Dispute Resolution. Cape Town: Juta \& Co Ltd
} 
to nor provide coverage for public sector employees. The implication of this is that, if an MNE extends its operations into Nigeria and directly or indirectly has to deal with workers in the public service, will it be possible that they could exploit the fact that the workers are not covered by the labor relations policy in Nigeria. The above two scenarios set the stage for the analysis of the possible role of MNEs in influencing the labour relations policy and law of a host nation.

\section{MULTINATIONAL ENTERPRISES: AN OVERVIEW}

The actions of multinational corporations are strongly supported by economic liberalism and the free market system in a globalized international society. According to the economic realist view, individuals act in rational ways to maximize their self-interest and therefore, when individuals act rationally, markets are created and they function best in a free market system where there is little government interference. As a result, international wealth is maximized through the free exchange of goods and services (Mingst, 2014, p.310).

To many economic liberals, multinational corporations are the vanguard of the liberal order (Mingst, 2014, p.311). They are the embodiment par excellence of the liberal ideal of an interdependent world economy. They have taken the integration of national economies beyond trade and money to the internationalization of production. For the first time in history, production, marketing, and investment are being organized on a global scale rather than in terms of isolated national economies (Gilpin, Robert 1975 p.39)

The other theoretical dimension of the role of multinational corporations concerns the relationship between the globalization of economic engagement and the culture of national and local responses. This has a history of self-conscious cultural management going back at least to the 1960s. For example, Ernest Dichter, architect, of Exxon's international campaign, writing in the Harvard Business Review in 1962, was fully aware that the means to overcoming cultural resistance depended on an "understanding" of the countries in which a corporation operated. He observed that companies with "foresight to capitalize on international opportunities" must recognize that "cultural anthropology will be an important tool for competitive marketing". However, the projected outcome of this was not the assimilation of international firms into national cultures, but the creation of a "world customer". The idea of a global corporate village entailed the management and reconstitution of parochial attachments to one's nation. It involved not a denial of the naturalness of national attachments, but an internationalization of the way a nation defines itself (James, Paul 1983 p.63).

\section{The nature of multinational enterprises}

A multinational corporation (MNC) is usually a large corporation incorporated in one country which produces or sells goods or services in various countries (Doob, 2013). The two main characteristics of MNCs are their large size and the fact that their worldwide activities are centrally controlled by the parent company. The roles and functions of MNEs include:

- Importing and exporting goods and services,

- Making significant investments in a foreign country,

- Buying and selling licenses in foreign markets,

- Engaging in contract manufacturing - permitting a local manufacturer in a foreign country to produce their products,

- Opening manufacturing facilities or assembly operations in foreign countries.

MNCs may gain from their global presence in a variety of ways. MNCs can benefit from (a) economy of scale by spreading R\&D expenditures and advertising costs over their global sales, (b) pooling global purchasing power over suppliers, and (c) utilizing their technological and 
managerial know-how globally with minimal additional costs, (d)using their global presence to take advantage of underpriced labor services available in certain developing countries, and (e)gaining access to special R\&D capabilities residing in advanced foreign countries (Eun \& Resnick (2017).

Clouding all of the above supposed benefits, however, still remains the problem of moral and legal constraints upon the behavior of multinational corporations in view of the fact that they are effectively "stateless" actors. This is one of several urgent global socio-economic problems that emerged during the late twentieth century (Gary, 2004).

Potentially, the best framework for analyzing society's governance limitations over modern MNEs is the concept of "stateless corporations" coined, at least, as early as 1990 in Business Week. The conception was theoretically clarified ${ }^{3}$ in 1992 by the view that an empirical strategy for defining a stateless corporation is with analytical tools at the intersection between demographic analysis and transportation research. According to Holstein (1990) and later Voorhees et al, (1992) this intersection is known as Logistics Management, and it describes the importance of rapidly increasing global mobility of resources. In the long history of analysis of multinational corporations, we are some quarter century into an era of stateless corporations corporations which meet the realities of the needs of source materials on a worldwide basis and to produce and customize products for individual countries (Holstein, 1990, p. 98).

One of the first multinational business organizations, the East India Company, was established in 1600 (Medard \& Bruner, 2003). After the East India Company, came the Dutch East India Company, founded March 20,1602, which would become the largest company in the world for nearly 200 years.

The main characteristics of multinational companies are:

- In general, there is a national strength of large companies as the main body, in the way of foreign direct investment or by acquiring local enterprises, established subsidiaries or branches in many countries;

- It usually has a complete decision-making system and the highest decision-making center, each subsidiary or branch has its own decision-making body, according to their different features and operations to make decisions, but its decision must be subordinated to the highest decision-making center;

- MNCs seek markets in worldwide and rational production layout, professional fixedpoint production, fixed-point sales products, in order to achieve maximum profit;

- Due to strong economic and technical strength, with fast information transmission, as well as funding for rapid cross-border transfers, the multinational has stronger competitiveness in the world;

- Many large multinational companies have varying degrees of monopoly in some area, due to economic and technical strength or production advantages.

"Multinational enterprise" (MNE) is the term used by international economists and similarly defined with the multinational corporation (MNC) as an enterprise that controls and manages production establishments, known as plants located in at least two countries (Caves, 2007 p.1). The multinational enterprise (MNE) engages in foreign direct investment (FDI) as the firm

\footnotetext{
3 The advancement of our understanding of the concept of the "stateless corporation" was aptly articulated by Yao-Su Hu (1992) "Global or Stateless corporations are national firms with international operations" California Management Review. Vol. 34, Issue No. 2 ( January 1), pp. 107 - 126 ( https://doi.org/10.2307/41166696) Retrieved: 02 May 2019
} 
makes direct investments in host country plants for equity ownership and managerial control to avoid some transaction costs across countries Caves, 2007 p.69).

A 'transnational corporation' differs from a traditional multinational corporation in that it does not identify itself with one national home. While traditional multinational corporations are national companies with foreign subsidiaries (Drucker, 1997, p. 167), transnational corporations spread out their operations in many countries to sustain high levels of local responsiveness.

An example of a transnational corporation is Nestlé, who employ senior executives from many countries and tries to make decisions from a global perspective rather than from one centralized headquarters (Schermerhorn, 2009). Another example is the Royal Dutch Shell Company, whose headquarters is in The Hague, Netherlands, but whose registered office and main executive body are headquartered in London, United Kingdom.

Multinational corporations may be subject to the laws and regulations of both their country of origin/domicile and the additional jurisdictions where they are engaged in business. In some cases, the jurisdiction can help to avoid burdensome laws, but regulatory statutes often target the "enterprise" with statutory language around "control" (Blumberg, 1990).

\section{Globalisation}

Another concept that is intricately related to the subject under examination in this paper is that of globalization. Globalization can be defined as a process of increasing global connectivity, integration and interdependence in the economic, social, technological, cultural, political and institutional spheres. Globalization refers, for instance, to the processes that reduce barriers between countries and involve greater integration in world markets, thus increasing the pressure for assimilation towards international standards (Ali, 2005; Frenkel and Peetz, 1998; Macdonald, 1997).

The economic aspects of globalization are the most visible and important ones. These include intensifying economic competition among nations, rapidly expanding international trade and financial flows and foreign direct investment (FDI) by multinational corporations (MNCs), disseminating advanced management practices and newer forms of work organization and, in some cases, sharing of internationally recognized labour standards.

Globalization enhances competitiveness, both at company level and national level, which leads company management and governments to adopt strategies designed to increase labour effectiveness in terms of productivity, quality and/or innovation. In general, globalization involves economies that are opening up to international competition and that do not discriminate against international capital. Therefore, globalization is often accompanied by a liberalization of the markets and the privatization of productive assets. At the same time, globalization has obviously contributed to raising unemployment, increasing casual employment and weakening labour movements (Ali, 2005)

The most important effects of economic globalization include the following:

- increasing integration of global economic activities,

- rising competitiveness,

- relocation of economic activities,

- structural changes in the economy,

- rapid technological advancements and innovation. 
Increased competition in global markets has created the demand for more specialized and better quality items. This has led to a higher volatility in product markets and shorter product life cycles which, in turn, requires companies to respond quicker to changes in market demand. In terms of production organization, new technologies increase the scope for greater flexibility in the production process and resolve any information and coordination difficulties which previously limited the production capacity of enterprises in different locations around the world (Macdonald 1997). Due to the growth in competitiveness, companies increasingly focus on the demands of international and domestic niche markets in a way that contributes to a growing individualization and 'de-collectivism' of work. Moreover, new technology has made it possible to produce the same level of production output with fewer workers. In both situations, an increased emphasis is placed on workers having higher value capacities and skills to perform a variety of jobs. This development has blurred the functional and hierarchical distinctions between different types of jobs and between labour and management in general.

In addition, efforts to improve products through innovation, quality, availability and pricing have led companies to set up cross-functional development teams, thus transcending the traditional boundaries between engineering, manufacturing and marketing. These developments have been accompanied by the erosion of the standardized, segmented, stable production process which had facilitated collective industrial relations (Macdonald, 1997).

These changes are also associated with a continuing shift in employment from manufacturing to service-oriented industries - in other words, jobs shift from traditional manual occupations to various forms of white-collar employment.

MNEs operations spread across the globe; they operate in industrial, commercial and services organizations. They have affiliates producing and selling through integrated networks in at least one or more other countries rather than merely selling abroad without fixed assets invested in such host countries (Fajana, 2000)

MNEs relocate a great deal of amounts of capital between countries as the need arises and they employ people of various nationalities in accordance to the prevailing labour laws in the host country. The subsidiaries are controlled by the financial, technological and managerial personnel at the headquarters. They are inevitably characterized by extremely large size, having in some cases, annual sales worth as much, in money terms, as the gross national product of some developing countries. (Fajana, 2000)

In more recent times, multinational corporations have grown in power and visibility, but have come to be viewed more ambivalently by both governments and consumers worldwide. Indeed, multinationals today are viewed with increased suspicion given their perceived lack of concern for the economic well-being of particular geographic regions and the public impression that multinationals are gaining power in relation to national government agencies, international trade federations and organizations, and local, national, and international labour organizations (Wilburn, 2003).

Despite such concerns, multinational corporations appear poised to expand their power and influence as barriers to international trade continue to be removed. Furthermore, the actual nature and methods of multinationals are in large measure misunderstood by the public, and their long-term influence is likely to be less sinister than imagined. Multinational corporations share many common traits, including the methods they use to penetrate new markets, the manner in which their overseas subsidiaries are tied to their headquarters operations, and 
their interaction with national governmental agencies and national and international labour organizations (Wilburn, 2003)

There are over 40,000 multinational corporations currently operating in the global economy, in addition to approximately 250,000 overseas affiliates running cross-continental businesses. In 1995, the top 200 multinational corporations had combined sales of USD \$7.1 trillion, which, at the time, was equivalent to 28.3 percent of the world's gross domestic product. The top multinational corporations are headquartered in the United States, Western Europe, and Japan; they have the capacity to shape global trade, production, and financial transactions. Multinational corporations are viewed by many as favoring their home operations when making difficult economic decisions, but this tendency is declining as companies are forced to respond to increasing global competition. (Francis, 1993).

Although foreign direct investment in developing countries rose considerably in the 1990s, not all developing countries benefited from these investments. Most of the foreign direct investment went to a very small number of lower and upper middle income developing countries in East Asia and Latin America. In these countries, the rate of economic growth is increasing and the number of people living at poverty level is falling. However, there are still nearly 140 developing countries that are showing very slow growth rates while the 24 richest, developed countries (plus another 10 to 12 newly industrialized countries) are benefiting from most of the economic growth and prosperity. Therefore, many people in the developing countries are still living in poverty (Wilburn, 2003).

Similarly, multinational corporations are viewed as being exploitative of both their workers and the local environment, given their relative lack of association with any given locality. This criticism of multinationals is valid to a point, but it must be remembered that no corporation can successfully operate without regard to local social, labor, and environmental standards, and that multinationals in large measure do conform to local standards in these regards. (Wilburn, 2003)

Multinational corporations are also seen as acquiring too much political and economic power in the modern business environment. Indeed, corporations are able to influence public policy to some degree by threatening to move jobs overseas, but companies are often prevented from employing this tactic given the need for highly trained workers to produce many products. Such workers can seldom be found in low-wage countries. Furthermore, once they enter a market, multinationals are bound by the same constraints as domestically owned concerns, and find it difficult to abandon the infrastructure they produced to enter the market in the first place.The modern multinational corporation is not necessarily headquartered in a wealthy nation. Many countries that were recently classified as part of the developing world, including Brazil, Taiwan, Kuwait, and Venezuela, are now home to large multinational concerns. The days of corporate colonization seem to be nearing an end (Wilburn, 2003).

While no one doubts the economic success and pervasiveness of multinational corporations, their motives and actions have been called into question by social welfare, environmental protection, and labor organizations and government agencies worldwide.

National and international labor unions have expressed concern that multinational corporations in economically developed countries can avoid labor negotiations by simply moving their jobs to developing countries where labor costs are markedly less. Labor organizations in developing countries face the converse of the same problem, as they are usually obliged to negotiate with the national subsidiary of the multinational corporation in 
their country, which is usually willing to negotiate contract terms only on the basis of domestic wage standards, which may be well below those in the parent company's country. Finally, government agencies fear the growing power of multinationals, which once again can use the threat of removing their operations from a country to secure favorable regulation and legislation. (Wilburn, 2003)

\section{Legislative/Instrumentality Imperatives for Multinational Enterprises' Labour Relations operations}

It is generally acknowledged that there is no legislation that can bind MNEs to adhere to higher labour standards in its operations than those applicable in the host country, but such international labor standard or instrument could have great persuasive force. It is also expedient to further give attention in this paper to some of such international instruments on the duties of MNEs with regard to employment relations. Such international instruments include:

\section{A - ILO Tripartite Declaration of Principles concerning MNEs and social policy (5 ${ }^{\text {th }}$ edition) $-2017^{4}$}

This Declaration sets out principles in the fields of employment, training, conditions of work and life, and industrial relations which governments, employers' and workers' organizations and multinational enterprises are recommended to observe on a voluntary basis; its principles shall not limit or otherwise affect obligations arising out of ratification of any ILO Convention (ILO, 2017).

The principles set out in the MNE Declaration are commended to governments, employers' and workers' organizations of home and host countries and to multinational enterprises themselves. The principles thereby reflect the fact that different actors have specific roles to play.

Multinational enterprises should fully take into account established general policy objectives of the countries in which they operate. Their activities should be consistent with national law and in harmony with the development priorities and social aims and structure of the country in which they operate. To this effect, consultations should be held between multinational enterprises, the government and, wherever appropriate, the national employers' and workers' organizations concerned.

\footnotetext{
4 "The Declaration provides that "All the parties affected by the MNE Declaration should respect the sovereign rights of States, obey the national laws and regulations, give due consideration to local practices and respect relevant international standards. They should also honour commitments which they have freely entered into, in conformity with the national law and accepted international obligations. They should respect the Universal Declaration of Human Rights (1948) and the corresponding International Covenants (1966) adopted by the General Assembly of the United Nations as well as the Constitution of the International Labour Organization and its principles according to which freedom of expression and association are essential to sustained progress.

All parties should contribute to the realization of the ILO Declaration on Fundamental Principles and Rights at Work and its follow-up, adopted in 1998. All Members, even if they have not ratified the fundamental Conventions in question, have an obligation, arising from the very fact of membership in the Organization, to respect, to promote and to realize, in good faith and in accordance with the Constitution, the principles concerning the fundamental rights which are the subject of those Conventions, namely: (a) freedom of association and the effective recognition of the right to collective bargaining; (b) the elimination of all forms of forced or compulsory labour; (c) the effective abolition of child labour; and (d) the elimination of discrimination in respect of employment and occupation. Governments of States which have not yet ratified the Conventions concerning fundamental principles and rights at work recognized in the 1998 Declaration are urged to do so. Multinational enterprises, through their operations, can contribute significantly to the attainment of its objectives" (ILO, 2017).
} 
Governments of host countries should promote good social practice in accordance with this declaration among multinational enterprises operating in their territories. Governments of home countries should promote good social practice in accordance with this Declaration among their multinational enterprises operating abroad, having regard to the social and labour law, regulations and practices in host countries as well as to relevant international standards. Both host and home country governments should be prepared to have consultations with each other, whenever the need arises, on the initiative of either (ILO, 2017).

\section{Industrial Relations}

Apart from adherence to generally accepted commercial practices, multinational enterprises should observe standards of industrial relations throughout their operations. This is often one of the most challenging issues experienced with MNEs. In the light of the ILO Declaration, the following aspects of labour relations often pose challenges to MNE operations in their host environments:

\section{Freedom of association and the right to organize.}

Workers employed by multinational enterprises as well as those employed by national enterprises should, without distinction whatsoever, have the right to establish and, subject only to the rules of the organization concerned, to join organizations of their own choosing without previous authorization. They should also enjoy adequate protection against acts of anti-union discrimination in respect of their employment (ILO, 2017).

Organizations representing multinational enterprises or the workers in their employment should enjoy adequate protection against any acts of interference by each other or each other's agents or members in their establishment, functioning or administration. Where appropriate, in the local circumstances, multinational enterprises should support representative employers' organizations. Governments, where they do not already do so, are urged to apply the principles of Convention No. 87, Article 5, in view of the importance, in relation to multinational enterprises, of permitting organizations representing such enterprises or the workers in their employment to affiliate with international organizations of employers and workers of their own choosing.

Where governments of host countries offer special incentives to attract foreign investment, these incentives should not include any limitation of the workers' freedom of association or the right to organize and bargain collectively.

Representatives of the workers in multinational and national enterprises should not be hindered from meeting for consultation and exchange of views among themselves, provided that the functioning of the operations of the enterprise and the normal procedures which govern relationships with representatives of the workers and their organizations are not thereby prejudiced (ILO, 2017).

Governments should not restrict the entry of representatives of employers' and workers' organizations who come from other countries at the invitation of the local or national organizations concerned for the purpose of consultation on matters of mutual concern, solely on the grounds that they seek entry in that capacity.

\section{Collective Bargaining}

Workers employed by multinational enterprises should have the right, in accordance with national law and practice, to have representative organizations of their own choosing recognized for the purpose of collective bargaining (ILO, 2017). 
Measures appropriate to national conditions should be taken to encourage and promote the full development and utilization of machinery for voluntary negotiation between employers or employers' organizations and workers' organizations, with a view to the regulation of terms and conditions of employment by means of collective agreements.

Multinational enterprises, as well as national enterprises, should provide workers' representatives with such facilities as may be necessary to assist in the development of effective collective agreements. Multinational enterprises should enable duly authorized representatives of the workers in their employment in each of the countries in which they operate to conduct negotiations with representatives of management who are authorized to take decisions on the matters under negotiation.

Multinational enterprises, in the context of bona fide negotiations with the workers' representatives on conditions of employment, or while workers are exercising the right to organize, should not threaten to utilize a capacity to transfer the whole or part of an operating unit from the country concerned in order to influence unfairly those negotiations or to hinder the exercise of the right to organize; nor should they transfer workers from affiliates in foreign countries with a view to undermining bona fide negotiations with the workers' representatives or the workers' exercise of their right to organize (ILO, 2017).

Collective agreements should include provisions for the settlement of disputes arising over their interpretation and application and for ensuring mutually respected rights and responsibilities. Multinational enterprises should provide workers' representatives with information required for meaningful negotiations with the entity involved and, where this accords with local law and practices, should also provide information to enable them to obtain a true and fair view of the performance of the entity or, where appropriate, of the enterprise as a whole (ILO, 2017).

Governments should supply to the representatives of workers' organizations on request, where law and practice so permit, information on the industries in which the enterprise operates, which would help in laying down objective criteria in the collective bargaining process. In this context, multinational as well as national enterprises should respond constructively to requests by governments for relevant information on their operations. (ILO, 2017).

\section{Consultation}

In multinational as well as in national enterprises, systems devised by mutual agreement between employers and workers and their representatives should provide, in accordance with national law and practice, for regular consultation on matters of mutual concern. Such consultation should not be a substitute for collective bargaining (ILO, 2017).

\section{Access to Remedy and Examination of Grievances}

As part of their duty to protect against business-related human rights abuses, governments should take appropriate steps to ensure, through judicial, administrative, legislative or other appropriate means, that when such abuses occur within their territory and/or jurisdiction any affected worker or workers have access to effective remedy (ILO, 2017).

Multinational enterprises should use their leverage to encourage their business partners to provide effective means of enabling remediation for abuses of internationally recognized human rights. 
Multinational as well as national enterprises should respect the right of the workers whom they employ to have all their grievances processed in a manner consistent with the following provision: any worker who, acting individually or jointly with other workers, considers that he or she has grounds for a grievance should have the right to submit such grievance without suffering any prejudice whatsoever as a result, and to have such grievance examined pursuant to an appropriate procedure. This is particularly important whenever the multinational enterprises operate in countries which do not abide by the principles of ILO Conventions pertaining to freedom of association, to the right to organize and bargain collectively, to discrimination, to child labour and to forced labour (ILO, 2017).

\section{Settlement of Industrial Disputes}

Governments should ensure that voluntary conciliation and arbitration machinery, appropriate to national conditions, is made available to assist in the prevention and settlement of industrial disputes between employers and workers. The procedure should be free of charge and expeditious. Multinational as well as national enterprises jointly with the representatives and organizations of the workers whom they employ should seek to establish voluntary conciliation machinery, appropriate to national conditions, which may include provisions for voluntary arbitration, to assist in the prevention and settlement of industrial disputes between employers and workers. The voluntary conciliation machinery should include equal representation of employers and workers (ILO, 2017).

\section{THE OECD GUIDELINES FOR MNES 5}

The OECD Guidelines for Multinational Enterprises are recommendations addressed by governments to multinational enterprises operating in or from adhering countries. They provide non-binding principles and standards for responsible business conduct in a global context consistent with applicable laws and internationally recognized standards. The Guidelines are the only multilaterally agreed and comprehensive code of responsible business conduct that governments have committed to promoting (OECD, 2011).

On 4 May 2010, the governments of the 42 OECD and non-OECD countries adhering to the OECD Declaration on International Investment and Multinational Enterprises and related Decision started work on updating the Guidelines to reflect changes in the landscape for international investment and multinational enterprises since the last review in 2000 . The changes agreed aim to ensure the continued role of the Guidelines as a leading international instrument for the promotion of responsible business conduct. The updated Guidelines and the related Decision were adopted by the 42 adhering governments on 25 May 2011 at the OECD's 50th Anniversary Ministerial Meeting (OCDE,2011).

\section{Employment and Industrial Relations}

Enterprises should, within the framework of applicable law, regulations and prevailing labour relations and employment practices and applicable international labour standards:

1a) Respect the right of workers employed by the multinational enterprise to establish or join trade unions and representative organizations of their own choosing.

b) Respect the right of workers employed by the multinational enterprise to have trade unions and representative organizations of their own choosing recognized for the purpose of collective bargaining, and engage in constructive negotiations,

5 “OECD Guidelines for Multinational Enterprises. 36 OECD Guidelines for Multinational Enterprises 2011Edition (C) OECD 2011) 
either individually or through employers' associations, with such representatives with a view to reaching agreements on terms and conditions of employment.

c) Contribute to the effective abolition of child labour, and take immediate and effective measures to secure the prohibition and elimination of the worst forms of child labour as a matter of urgency.

d) Contribute to the elimination of all forms of forced or compulsory labour and take adequate steps to ensure that forced or compulsory labour does not exist in their operations.

e) Be guided throughout their operations by the principle of equality of opportunity and treatment in employment and not discriminate against their workers with respect to employment or occupation on such grounds as race, colour, sex, religion, political opinion, national extraction or social origin, or other status, unless selectivity concerning worker characteristics furthers established governmental policies which specifically promote greater equality of employment opportunity or relates to the inherent requirements of a job.

2a) Provide such facilities to workers' representatives as may be necessary to assist in the development of effective collective agreements.

b) Provide information to workers' representatives which is needed for meaningful negotiations on conditions of employment.

c) Provide information to workers and their representatives which enables them to obtain a true and fair view of the performance of the entity or, where appropriate, the enterprise as a whole.

3. Promote consultation and co-operation between employers and workers and their representatives on matters of mutual concern.

4a) Observe standards of employment and industrial relations not less favourable than those observed by comparable employers in the host country

b) When multinational enterprises operate in developing countries, where comparable employers may not exist, provide the best possible wages, benefits and conditions of work, within the framework of government policies. These should be related to the economic position of the enterprise, but should be at least adequate to satisfy the basic needs of the workers and their families.

c) Take adequate steps to ensure occupational health and safety in their operations.

5. In their operations, to the greatest extent practicable, employ local workers and provide training with a view to improving skill levels, in co-operation with worker representatives and, where appropriate, relevant governmental authorities.

6. In considering changes in their operations which would have major employment effects, in particular in the case of the closure of an entity involving collective lay-offs or dismissals, provide reasonable notice of such changes to representatives of the workers in their employment and their organizations, and, where appropriate, to the relevant governmental authorities, and co-operate with the worker representatives and appropriate governmental authorities so as to mitigate to the maximum extent practicable adverse effects. In light of the specific circumstances of each case, it would be appropriate if management were able to give such notice prior to the final decision being taken. Other means may also be employed to provide meaningful co-operation to mitigate the effects of such decisions.

7. In the context of bona fide negotiations with workers' representatives on conditions of employment, or while workers are exercising a right to organize, not threaten to transfer the whole or part of an operating unit from the country concerned nor transfer workers from the enterprises' component entities in other countries in order to influence unfairly those negotiations or to hinder the exercise of a right to organize. 
8. Enable authorized representatives of the workers in their employment to negotiate on collective bargaining or labour-management relations issues and allow the parties to consult on matters of mutual concern with representatives of management who are authorized to take decisions on these matters.

\section{D - UN PRINCIPLES AND THE GLOBAL COMPACT6}

The UN Global Compact is a principle-based framework for businesses that states ten principles in the areas of human rights, labor, the environment and anti-corruption. Under the Global Compact, companies are brought together with UN agencies, labor groups and civil society. The United Nations Global Compact is a non-binding United Nations pact to encourage businesses worldwide to adopt sustainable and socially responsible policies, and to report on their implementation (UNGC, 2014).

The UN Global Compact is the world's largest corporate sustainability (a.k.a. corporate social responsibility) initiative with 13000 corporate participants and other stakeholders over 170 countries with two objectives: "Mainstream the ten principles in business activities around the world" and "Catalyze actions in support of broader UN goals, such as the Millennium Development Goals (MDGs) and Sustainable Development Goals (SDGs)". Moving forward, the UN Global Compact and its signatories are deeply invested and enthusiastic about supporting work towards the SDGs (UNGC, 2014).

However, corporate sustainability starts with a company's value system and a principles-based approach to doing business. This means operating in ways that, at a minimum, meet fundamental responsibilities in the areas of human rights, labour, environment and anticorruption. Responsible businesses enact the same values and principles wherever they have a presence, and know that good practices in one area do not offset harm in another. By incorporating the Ten Principles of the UN Global Compact into strategies, policies and procedures, and establishing a culture of integrity, companies are not only upholding their basic responsibilities to people and planet, but also setting the stage for long-term success (UNGC, 2014).

\section{THE KING CODE IV IN SOUTH AFRICA ${ }^{7}$}

The King Report and King Code defines corporate governance as "the exercise of ethical and effective leadership by the governing body". The use of "corporate" in terms of "corporate governance" is used to differentiate it from other forms of governance, for example national or political governance. Corporate refers to organizations that are incorporated to form as legal entities separate from their founders and therefore applies to all forms incorporation whether as company, voluntary organization, legislated entities.

King Report and King Code is important in this context because it sets out ethical and effective leadership conduct for business leadership in general. It was first published in 1994. The previous King Code reports include: King I, King II, King III, with King IV ${ }^{\mathrm{T}}$ being the latest edition (The King IV effective date was 1 April 2017). The King Reports have undergone many

\footnotetext{
${ }^{6}$ For the purpose of this paper the focus is placed only on the labour relations aspect of the UN Global Compact that expresses the principle that: "businesses should uphold the freedom of association and the effective recognition of the right to collective bargaining; the elimination of all forms of forced and compulsory labour; the effective abolition of child labour; and the elimination of discrimination in respect of employment and occupation (UNGC, 2014).

${ }^{7}$ Refer to The Institute of Directors of Southern Africa NPC (2016)
} 
changes since 1994. With all the changes in business (such as technological changes) it was inevitable that the King Report and King Code would have to be updated from time to time. Each version of the King reports builds on the one before. Although King IV is based on the underlying principles of the previous King Reports, it now emphasizes a more stakeholder inclusion approach.

The purpose of King Code is to:

- encourage an ethical culture in organizations,

- improve their performance and increase the value they create,

- ensure that there are adequate and effective controls in place,

- build trust amongst all stakeholders,

- ensure the organization has a good reputation,

- ensure legitimacy.

The King Code applies to all organizations, including organizations listed on the JSE, unlisted companies, Trusts and NGO's. The King Code has always applied to all organizations but because of its complexity, smaller organizations have seldom applied the principles. The latest version tried to address this by making it simpler and easier to understand. Smaller organizations and NGOs will therefore find it easier to apply the principles to their organization. The King Code is voluntary. parties do not have to comply. King IV is more effective as it contains all the principles of the previous King reports but it is updated.

By updating the Report, it is keeping up with international practices. Other countries have codes similar to the King Codes. These countries include the US, Canada and Australia The content is applicable to the current needs of the business world.

King III had 75 principles whereas King IV only has 17 principles in. The 17 th principle only applies to institutional investors, so organizations are left with 16 principles that they have to comply with. The King IV report has been scaled down to only 82 pages. Previously the codes and reports were published separately but King IV integrates the code into the report. The Report has decreased in size and is more applicable to its audience. The document is easier to read and understand. This helps smaller companies to apply the principles in their businesses. Finally, in the examination of international instrument such as ILO and OECD Declarations and their various principles and codes they have adopted, it is vividly identified that there is a commonality inherent among various principles and framework that guide the conduct of multinational enterprise within the host nation which is voluntary and non-binding principles of the international instruments. However, this simply implies that the host nation's legislative framework or domestic labor laws undoubtedly supersede international frameworks or foreign laws.

These measures and principles put in place by the international body to regulate the affairs of MNEs will adequately be successful in ensuring that MNEs do not participate in the "race to the bottom" which may consequently, in effect have an opposite or a negative effect in host countries (especially those countries with lower standards), namely, to raise labour standards, train employees etc. On the other hand, they encourage those countries with already higher labour standards to continue to maintain them. 


\section{ANALYSES OF THE INFLUENCE OF MNES ON LABOUR RELATIONS OF SELECTED AFRICAN COUNTRIES}

The exercise at this point is to examine the ways MNEs have attempted to influence the labour relations policy (and laws) of their host nation. In undertaking this analysis,selected countries in three geographical regions (eastern, western and southern) were examined, as follows:

\section{Nigeria}

While the first case scenario examined in Nigeria relates more to the general commercial and fiscal compliance (or non-compliance) activities of an MNE, it is the position of this paper that ultimately, the outcome of such activities has implications for the employment relations environment of the host nation. The Central Bank of Nigeria (CBN) lodged a dispute against a major telecommunications MNE (MTN Nigeria, established in 2001 as a subsidiary of the giant, global telecommunications group with headquarters in South Africa) for breaching the country's monetary and foreign exchange regulations in that CBN alleged that the said corporation, in collusion with four other domestic banks, between 2007 and 2015, irregularly and illegally transferred huge amounts of funds out of Nigeria. This action was deemed to have been in breach of the Central Bank of Nigeria (CBN) Act, the Foreign Exchange (Monitoring and Miscellaneous Provisions) Act, and the Money Laundering (Prohibition) Act, Section 20(1). The CBN demanded that the MNE repatriate, back into Nigeria, the amount of USD\$8.1 billion being the value of the transferred funds. The matter was eventually settled after the MNE negotiated to pay USD \$52.6 million. The colluding local banks were fined USD \$16 million. Consequent upon this allegation, the Attorney-General of the Federation also sued the MNE for taxes to the tune of USD $\$ 2$ billion. As is to be expected, the MNE denied all the allegations.

An interesting development in this matter was contained in a national news media report (This Day Newspaper of $25^{\text {th }}$ October, 2018) in which the Nigerian Minister of Finance, Zainab Ahmed, declared that the above case, amongst others, was having a "negative effect on investor confidence, i.e, foreign direct investment into Nigeria. As the literature (Eun \& Resnick, 2017; Wilburn, 2003) has shown, this is one of the refrains often used to bolster and overlook certain MNE excesses in their host nations. The other argument that was advanced by the MNE in this case, was that the impositions would compel them to further cut down on labour costs ${ }^{8}$ and effectively negatively influence the employment situation in the country.

Prior to the above developments, the same MNE had, in October 2015, been fined the sum of USD $\$ 5.2$ billion by the telecommunication regulatory authority, the Nigerian Communications Commission for contravening regulatory requirements in that it had failed to disconnect, as instructed, 5.1 million unregistered SIM cards on its Nigerian network. The MNE eventually reached a settlement with the authorities and was let off the hook paying a reduced amount of USD\$1.671 billion. Commenting on the above two cases, Ofentse Dazela, a telecommunications analyst observed that "while companies in all markets are subject to rules and regulations, the 'noise' coming from Nigeria around compliance is now a cause for concern for stakeholders with vested interests in that market. Despite the setbacks some commentators, such as

\footnotetext{
8 It is noteworthy that while investigations on this matter was on-going, Emma Okonji, a journalist with This Day Newspaper of 2 May, 2017, reported that the company had already laid off 280 employees, representing almost 17 percent of the permanent workforce ostensibly as part of a voluntary severance scheme. This goes to underscore how labour can easily become the 'collateral damage' in the event of an MNE malfeasance. MYN Nigeria has sine its commencement of operations in Nigeria craftily discouraged the unionization of its workforce. See also IOL Business Report of 13 September, 2018 https://www.iol.co.za/business-report/.../mtn-hit-by-mounting-offshorewoes Retrieved: 30 April, 2019.
} 
Chikanga (2018), believe that the MNE would mend their relationship with the Nigerian authorities as they generate up to 30 percent of their business revenue from that market.

\section{South Africa}

The South African case related to a dispute of how a competently drafted contract agreement saved an organization millions of rand. The matter of the Commissioner for SARS v Reunert Ltd ${ }^{9}$ highlights the importance of possessing an intimate understanding of contractual principles when drafting agreements. In this case, SARS found itself at the losing end of a Supreme Court of Appeal judgment, handed down by the Honourable Cachalia JA on 22 November 2017, due to misinterpretation of certain clauses in a contract.

\section{The agreement}

When Nokia Siemens Networks (NSN, now known as Nokia Networks), the MNE, decided to separate control of the rest of Southern Africa from Nokia Siemens Networks South Africa (NSN-SA), the business unit experienced a sharp decline in income. Consequently, Reunert Ltd, a local group with a $40 \%$ shareholding in NSN-SA, saw its dividend drop to unsatisfactory levels and therefore asked NSN to buy back its shares. NSN, however, recognizing Reunert as a valued business partner with strong ties to its biggest South African customers, proposed an alternative.

NSN entered into a Sales Promotion Agreement (SPA) with Reunert whereby the latter was appointed as their sales promoter. In terms of the SPA, NSN calculates a hypothetical sales commission every six months from its total Southern African turnover, representative of Reunert's previously-enjoyed dividends. Any current dividend paid by NSN-SA is deducted from the gross commission and the net commission accrues to Reunert. However, if the dividend is greater than the gross commission, Reunert does not receive any commission.

\section{SARS dispute}

For the 2008 and 2009 years of assessment, Reunert dutifully declared net commissions for taxation. SARS, however, asserted that the terms of the SPA entitled Reunert to the total commissions regardless of the subsequent deduction of the dividend. The authority therefore raised additional assessments for both periods (totaling a combined R80 million) to claim tax on the entire amount.

Due to this difference in interpretation of the SPA, Reunert sought relief from the Tax Court and was awarded judgment in its favor. SARS appealed the ruling and arguments were heard from both parties by the Supreme Court of Appeal. Ultimately, the honorable judge upheld the previous ruling in favor of the taxpayer and dismissed SARS' plea.

\section{Interpretation}

The dispute hinged mainly on the wording of three clauses in the SPA. Clause 4.1 set out the rules for calculating the gross commission as a percentage of NSN-SA's turnover, and was "subject to" clause 4.9. Clause 4.9 stipulated that the actual commission payable was arrived at by deducting any current dividend from the gross commission. Lastly, clause 4.10 enabled the sales revenue for each period to be converted from Euros to Rand based on the average exchange rate for each month for the purpose of calculating the commission.

9 The Commissioner of the South African Revenue Service v Reunert Ltd (9712016 [2017] ZASCA 153 (22 November 2017) 
SARS argued that, in terms of clause 4.10, it was possible to calculate the gross commission on a monthly basis, making the commission due at the time of sale. They backed up this argument with a note from Reunert's 2009 and 2010 annual financial statements which said that "NSN may pay a dividend to Reunert as a method of settlement of commission income."

Reunert responded to the above argument by stating that because clause 4.1 was "subject to" 4.9 , they were never unconditionally entitled to the gross commission and that the note from the financials was made in error.

\section{Outcome}

Although the court frowned upon the inconsistency of the note with the terms of the SPA, it agreed that Reunert's interpretation of the contract's clauses were unquestionably correct. This was further strengthened by the company's testimonies and evidence on the background and implementation of the contract. SARS' appeal was therefore denied.

The takeaway is that the terminology of contractual clauses cannot be isolated from their context. The court looked at three aspects of the entire agreement. First, it considered the meaning of the words within the contract, analyzing specific terms individually. Second, it decided if the clauses, taken separately and as a whole, resulted in a valid commercial intention. Third, the court objectively reviewed the testimonies and evidence presented to assure itself that the agreement's implementation accorded with its terms.

The most important principle here is that of contract drafting. Because the drafter of the SPA made clause 4.1 and clause 4.9 inseparable, the taxpayer saved R80 million. This is a perfect example of applying sufficient preparation and employing drafters with extensive contract and tax knowledge (Christopher Renwick, 2017).

\section{Zambia}

In Zambia, disputes in the construction industry are often inevitable. Disputes arise from the interpretation and application of any part of ambiguous, unplanned, and conflicting contract documents (Musonda \& Muya, 2011). The Zambian government entered into a contract with China's national construction company, however, as a result of poor due diligence exercise, they believed that they were granting consent to genuine terms only to realize later that the terms were disgracefully unfavourable to their national interest. Some commentators even referred to the deal as a classical example of neo-colonialism, a tendency that is not seen as new in the dealings of certain MNEs, particularly in Africa (Williams, Davies, Lamptey \& Tetteh, 2017). As a result of the flaws in this deal, China is now proposing to take over the Kenneth Kaunda International Airport should the Zambian Government fail to pay back its huge foreign debt on time. The issue of whether Zambia possess the required economic muscle to repay that debt is in contention considering the amount involved. It's typical of the Chinese strategy (Richard Krah, 2018).

Krah (2018) has also observed that the modus operandi of Chinese MNEs in Zambia does not bode well for the economic future of the country in that as part of another transaction, the Chinese deftly assigned $60 \%$ of the shares of the Zambian National Broadcasting Corporation to themselves, are threatening to take ownership of the broadcaster if the government fails to meet their loan obligations undertaken through an MNE-linked investment in the country. The potential implication of this threat is that in the event of a default, by the Zambian government, the Chinese have an influence over what information should or should not be broadcast to Zambian nationals. 
Against this backdrop of intensifying economic interaction, public opinion and media coverage have paid special attention to the employment practices of Chinese companies in Africa. Much of this publicity is negative. Some observer's express concern that Chinese companies prefer to bring a large number of Chinese workers to Africa and are unwilling to hire local workers (Tang Xiaoyang, 2016). Ben Schiller reported that tens of thousands of Chinese laborers and engineers were imported to build infrastructure projects in Ethiopia, Sudan and other African countries. This makes the acute unemployment problem in Africa even worse (Tang Xiaoyang, 2016).

China's first Zambian concession, in the town of Chambishi, was dogged by reports of labor abuses, including low pay and poor safety conditions. An explosion (accident at the Beijing General Research Institute of Mining and Metallurgy (BGRIMM) near the mine killed 46 Zambian workers in 2005, its first year of operations, and sparked further outcry when reports emerged that Chinese supervisors had run for cover immediately before the blast and failed to warn their Zambian staff of looming danger (Rosen, 2018).

In 2006, a salary dispute at the mine resulted in workers vandalizing equipment and beating up a Chinese manager; another Chinese supervisor retaliated by wounding several Zambians with a shotgun. Then, as now, anti-Chinese sentiment became a lynchpin of opposition politics. Michael Sata, who unsuccessfully contested Zambia's 2006 presidential election, undiplomatically described the Chinese as "infesters" rather than investors, and accused his opponent of handing away Zambia's sovereignty (Rosen, 2018).

\section{DISCUSSION AND RECOMMENDATIONS}

Generally, most of the MNEs will continuously want to repatriate capital from the subsidiary and move it to their headquarters, which absolutely results in capital flight, which may in the long run have negative effect on the economy of the host nation. Based on the cases sited above, it is obvious that the parent company of MNE in the Nigerian case did repatriate capital from the country without following due process in an attempt to circumvent foreign exchange regulations in Nigeria

Though generally, there are no international regulations restricting MNEs from transferring funds, MNEs are still expected to give regard to the processes established by their host nation. Similarly, the requirements for the payment of taxes cannot arbitrarily be circumvented by MNEs. At this junction, question need to be asked; how was it that the Central Bank of Nigeria and the tax authority failed to detect both the allegedly illegal transfer of dividends and the failure to pay tax for so many years? This can be general linked laxness on the part of Nigeria government not performing their duties as it regards to foreign investment.

Aspects of labor laws advanced by the International Labor Organization include the freedom of association of employees to join unions and to collectively bargain issues that concern employee's terms and conditions. In Nigeria, for instance, the leadership of the Nigeria Labor Congress (NLC), one of the labour federations, has complained over non-compliance to labor laws and the refusal of MTN Nigeria to allow unionization in their organization. Nonunionization in the MNEs has hindered both effective industrial centralized collective bargaining and effectively dealing with employee - employer grievances specific to the industry. These, put together, in one sense explain how multinational enterprises attempt to truncate labor relations policy in the host country.

The Zambia case that led to the killing of some workers can directly be attributed to poor working environment because the Chinese multinational enterprise had not followed rules and 
guidelines pertaining to the safety precautions that exist in the host nation. Observance of these health and safety standards, especially in the mining sector, by MNEs cannot be overemphasized. The alleged anti-labour practices of Chinese MNEs have often been criticized by both local and international commentators In China, it is claimed that thousands of Chinese workers die in mining accidents every year as a result of lax regulation and ineffective implementation (Tang Xiaoyang, 2016). Safety records in China's domestic mines are poor and their MNEs appear to be exporting these practices to their foreign operations. These antilabour practices have been found not to be limited to shealth and safety issues as one study by CK. Lee reported that even some of the major Chinese MNEs such as NFC Africa Mining Plc of Zambia was complicit in paying some of the lowest wages to its employees (Tang Xiaoyang, 2016).

Though, the general perception amongst writers and commentators is that MNEs widely have a negative influence on the commercial and labour standards of their host nations, of the countries examined, South Africa appears to have in place very stringent legislative safeguards for workers in the country even though that does not provide sufficient safeguard against attempts on commercial or fiscal manipulations by MNEs.

\section{CONCLUDING REMARKS}

This paper has therefore highlighted some of the gaps in commercial compliance, but also with regard to the labour relations policy, that continues to exist in relation to how MNEs operate in the selected host nations.

The paper further reveals that the existing international instruments (ILO, OECD, and even domestic corporate governance provision like the King codes in South Africa) do not go far enough to give the 'bite' that they should have in guiding the operations of MNEs especially since they are essentially organisations that cut across territorial boundaries of independent nations. Thus countries' only recourse in contending with the excesses of certain MNEs is only to apply their domestic legislation even when such legislation may be glaringly inadequate to fully address the challenges that MNEs may pose. Whilst it is hoped that MNEs would contribute to the economic growth of their host nations, the myriad of challenges they come with are beginning to erode some of the benefits associated with their presence in the host nations. Some of these include attempts to circumvent the monetary and economic of fiscal policies of the host nation, contractual underhandedness, inadequate observance of health and safety provisions and ultimately an adverse influence on employment and labour relations policy.

\section{References}

Ali, M. (2005). "Globalization and industrial relations of China, India and South Korea: An Argument for divergence". Schmidt Labor Research Center Seminar Paper Series, University of Rhode Island.

Barton, Ron, \& Michael Bishko. (1998) "Global Mobility Strategy." HR Focus.

Briscoe, D., Schuler, D., \& Tarique, I. (2012). International Human Resource /Management - Policies and Practices for Mulltinational Enterprises (4th Edn.) New York: Routledge.

Burton, Daniel F., Jr., Erich Bloch, Mark S. (1994) Multinational Challenges.Case study: The Relationship between the Structure/Strategy of Multinational Corp-orations and Patterns of Knowledge Sharing within them (PDF). Oxford University Press. 2009

Caves, Richard, E. (2007). Multinational enterprise and economic analysis. UK: Cambridge University Press

Chang, Sea-Jin, \& Philip M. Rosenzweig (1998). "Industry and Regional Patterns in Sequential Foreign Market Entry." Journal of Management Studies. 
Chikanga, Derrick (2018). MTN Nigeria trying to fix a USD $\$ 2$ billion tax dispute in court. Quartz Africa Online https://www.iol.co.za/business-report/.../mtn-hit-by-mounting-offshore-woes. Retrieved: 27 April, 2019

Choucri, Nazli (1991). "The Global Environment and Multinational Corporations" Technology Review Dobbs, Lou (2004) "The Myth of Insourcing." U.S. News \& World Report, 56(3 May)

Doob, Christopher M. (2013). Social Inequality and Social Stratification in US Society. Pearson Education Inc.

Drucker, Peter F. (1997). The Global Economy and the Nation State. Council on Foreign Relations. p. 167

Eun, Cheol S.; \& Resnick, Bruce G. (2017). International Financial Management, (8th Edition). NY: McGraw-Hill Higher Education Education.

Eweje, G. (2009). "Labour relations and ethical dilemmas of extractive MNEs in Nigeria, South Africa and Zambia: 1950 - 2000" Journal of Business Ethics, 86, 207 - 223

Fajana, S. (2000). Functioning of the Nigerian Labour Market. Indiana University: Labofin

Francis, Diane. (1993) "The New Love Affair with Transnationals." Maclean's Magazine Online.

$\mathrm{https//www.archive.macleans.ca/article/1993/12/20/the-new-love-affair-with-transnationals} \mathrm{Retrieved:} 1$ May 2019

Frenkel, S. and Peetz, D. (1998). "Globalization and industrial relations in East Asia: A three-country comparison". Industrial Relations, Vol. 37, No. 3, pp. 282-310.

Gilpin, Robert (1975) US power and the multinational corporation: The political economy of foreign direct investment. New York: Basic Books

Hatfield, John. (1998) "At the Mercy of the Monsters." CA Magazine.

Holstein, William J. (1990) "The Stateless Corporation", Business Week News Magazine (May 14) p. 98.

International Labour Organization (2017). "Tripartite Declaration of Principles concerning Multinational Enterprises and Social Policy (MNE Declaration)" - (5th Edition) https://www.ilo.org/empent/areas/mnedeclaration/lang--en/index.htm Retrieved: 2 May 2019

Iyanda, O. \& Bello, J. A. (1979) “Employment effects of multinational enterprises in Nigeria” Multi-national Enterprises Programmes Working Papers (Working Paper No, 10. Geneva: International Labour Office.

James, Paul (1983). "Australia in the Corporate Image: A New Nationalism". Arena (63):

Jane, Wills. (1998) "Taking on the Cosmo Corps?" Economic Geography.

Koenig-Archibugi, Mathias \& Gary (2004). "Transnational Corporations and Public Accountability" (PDF). Gary 2004: 106. Retrieved 2 February 2015

Krah, Richard (2018). "China to take over Zambian International Airport for Debt Repayment Default; Neocolonialism?" (11 September) Committee for the Abolishment of Illegitimate Debt. www.cadtm.org/China-totake-over-Zambian-international-Airport-for-debt-repayme Retrieved: 30 March, 2019

Krugman, Paul (1997, 20 March). "In Praise of Cheap Labor: Bad Jobs at Bad Wages Are Better than No Jobs at All". Slate. Retrieved 2 February 2019.

Macdonald, D. (1997). "Industrial relations and globalization: Challenges for employers and their organizations". Paper presented at the ILO Workshop on employers' organizations in Asia-Pacific in the twenty-first century, Turin, Italy, 5-13 May.

Mataloni, Raymond J. (1998) "U.S. Multinational Companies Operations in 1996." Survey of Current Business, September 1998.

Medard Gabel \& Bruner, Henry (2003). An Atlas of the Multinational Corporation. New York: The New Press. ISBN 1-56584-727-X". Archived from the original on 2003-12-22.

Mingst, K. A. (2014). Essentials of international relations. W. W. Norton \& Company.

p. 310. ISBN 978-0-393-92195-3.

Miller, William H. (1999) "A Force for Good." Industry Week, 19 April 1999.

Nuruzzaman, Mohammed. (2005) "Economic Liberalization and Poverty in the Developing countries. "Journal of Contemporary Asia, March 2005, 109

Onimode, B. (1978). "Imperialism and multi-national corporations: A case study of Nigeria" Journal of Black Studies, 9, (2), $207-232$. 
Allen-ILE, C., \& Olabiyi, O. (2019). A preliminary comparative perspective on the role of multinational enterprises in influencing labour relations of their host nation. Advances in Social Sciences Research Journal, 6(12) 298-318.

Blumberg, P. (1990). “The corporate entity in an era of multinational corporations". Del. Journal of Corp. Law, 15, 283

Prahalad, C.K., \& Lieberthal, K. (1998). “The End of Corporate Imperialism” Harvard Business Review (July August)

Richard, Barnet \& Muller, R. (1974). Global Reach: The Power of Multinational Corporations New York: Simon and Schuster.

Rosen, Jonathan, W (2018). "China wants to lend and lend, but at what cost to Zambia and the rest of Africa?" World Politics Review Online.https://www.worldpoliticsreview.com/.../china-wants-to-lend-and-lend-but-atwhat-cos Retrieved 4 April, 2019

Schermerhorn, John R. (2009) Exploring Management (4th edition) Wiley Global Education.

Stopford, John (1998). "Multinational Corporations." Foreign Policy, (Winter).

Tang Xiaoyang (2016) “Does Chinese Employment Benefit Africans? Investigating Chinese Enterprises and their Operations in Africa”. African Studies Quarterly / Volume 16, Issue 3-4 |.

"Time to Bring it Back Home?" The Economist, 5 March 2005, 63.

ThisDay Newspaper (2017, 2 May) “MTN Nigeria downsizes, sacks over 280 workers (Emma Okonji, Reporter) Tsang, Eric W.K(1999). "Internationalization as a Learning Process: Singapore MNCs in China." Academy of Management Executives, February 1999.

Tyler, Gus (1993). "The Nation-State vs. the Global Economy." Challenge (March-April 1993).

UNGC (2014) Two United Nations Plaza New York, NY 10017, USA global compact

Voorhees, Roy, D.; Seim,Emmerson, L. \& Coppett, John, I. (1992) "Global Logistics and Stateless

Corporations", Transportation Practitioners Journal 59, 2 (Winter ): pp. 144-51.

Wilburn, Rhoda, L. (2003) "Multinational corporations" https://www.referenceforbusiness.com/management/Mar-No/Multinational-Corporations.html . Retrieved: 1 May 2019

Williams, G, Davies, S, Lamptey \& Tetteh, J (2017. “Chinese multinationals: Threat to, or opportunity for trade unions? The case of sinohydro in Ghana" Working Paper Number 46 (May) Global Labour University, Berlin: International Labour Organisation

Woollacott, Martin (1995). "Are Businesses Forced to Keep Bad Company?" Business and Society Review, 45 (Fall 1995).

"Worldbeater Inc." Economist, 22 November 1997.

Zhao, Laixun (1998). "Labour-Management Bargaining and Transfer Pricing in Multinational Corporations." Canadian Journal of Economics, October 1998. https://www.referenceforbusiness.com/management/Mar-No/Multinational-Corporations.html\#ixzz5hFRgiEHK Retrieved: 26 April, 2019 